\title{
Anetoderma: Is It a Sign of Autoimmunity?
}

\author{
Hessa Al Buainain ${ }^{a} \quad$ Mohamed Allam $^{b}$ \\ aDermatology Department, Rumailah Hospital, Hamad Medical Corporation, \\ Doha, 'bermatology Department, Al Khor Hospital, Hamad Medical Corporation, \\ Al Khor, Qatar
}

\section{Key Words}

Anetoderma - Thyroid · Autoimmune thyroiditis · Grave's disease - Primary hypothyroidism

\begin{abstract}
Anetoderma is a rare elastolytic disorder characterized by circumscribed areas of flaccid skin due to the loss of elastic tissue in the dermis. Primary anetoderma is frequently observed in patients with autoimmune diseases or abnormalities especially with antiphospholipid antibodies with or without antiphospholipid syndrome. In this case report we discuss a patient with primary anetoderma with positive antithyroid peroxidase antibodies, which is consistent with autoimmune thyroiditis.
\end{abstract}

\section{Case Report}

A 42-year-old Indian male had multiple small circumscribed wrinkled sacs like lesions on the shoulders and upper back of 4 months duration (fig. 1). It was not preceded by any inflammatory skin lesions. Skin biopsy was taken for histopathological examination and revealed minimal dermal perivascular chronic inflammatory cells infiltrate (fig. 2). Elastic stain (Verhoef-Van Gieson) showed loss of elastic fibers in the superficial dermis (fig. 3 ) and the diagnosis was consistent with anetoderma. Direct immunofluorescence (DIF) was negative for IgA, IgG, IgM, C1q, C3 and fibrinogen. CBC, ESR, and routine chemistry were normal. The patient did not have any symptoms or show any sings of antiphospholipid syndrome (APS), and screening for antiphospholipid antibodies (anticardiolipin profile, anti- $\beta$-2-glycoprotein, IgG and IgM, and lupus anticoagulant) were all negative. Also, PT, PTT and INR were within normal range. RPR, VDRL, treponema pallidum antibodies were negative. Antinuclear antibody (ANA), ENA screen (SMB, SMD, RNP-70, and RNP-A, RNP-C, SSA/RO52, SSA/RO60, SSB/LA, CENP-B, SCL-70, JO-1, Ribosomal P and histones) were negative. Thyroid panel test showed normal free thyroxine and thyroid stimulating hormone, but the patient had a positive high titer of thyroid peroxidase antibody (anti-TPO antibody) $>116 \mathrm{IU} / \mathrm{ml}$. Positive anti-TPO antibody is consistent with autoimmune thyroiditis. 


\section{Discussion}

There are numerous reports and studies that link primary anetoderma (PA) to lupus erythematosus, but the relation has not been clearly established [1-14]. Moreover, there are isolated repots of PA and autoimmune diseases like primary hypothyroidism [15], Grave's disease [16], Addison's disease [14], Sjogren's syndrome [17], alopecia areata [18], vitiligo $[14,18,19]$ and multiple sclerosis [20]. Now, there is a growing body of evidence to consider PA as a cutaneous sign of positive antiphospholipid antibodies with or without fulfilling the criteria of APS [16, 21-34]. In our case, there is a high titer of antithyroid peroxidase antibodies, which is consistent with autoimmune thyroiditis. This is in accordance with the work of Hodak et al. [16] who described a case of PA with Grave's disease, positive lupus anticoagulant and autoimmune hemolysis. It is important to mention that Grave's disease in the study of Hodak et al. [16] had started 5 years after the onset of the PA. In our study, there were no clinical signs or symptoms of thyroid disease at the time of diagnosis; also free thyroxine and thyroid stimulating hormone were in a normal range, but we have to take the short duration of onset of PA in our case into consideration.

Also, Bergman et al. [15] described a case of primary hypothyroidism that developed 3 years after the onset of anetoderma. From our point of view and the aforementioned literature we have to think of PA as a cutaneous sign of autoimmunity and patients should be examined and carefully tested for autoimmune diseases, especially for antiphospholipid antibodies, lupus erythematosus and also thyroid antibodies. Patients should also be followed up because associated autoimmune diseases may develop later in the course of the disease, maybe years after the onset of anetoderma. 
Fig. 1. Multiple small circumscribed wrinkled sacs like lesions on the shoulders and upper back.

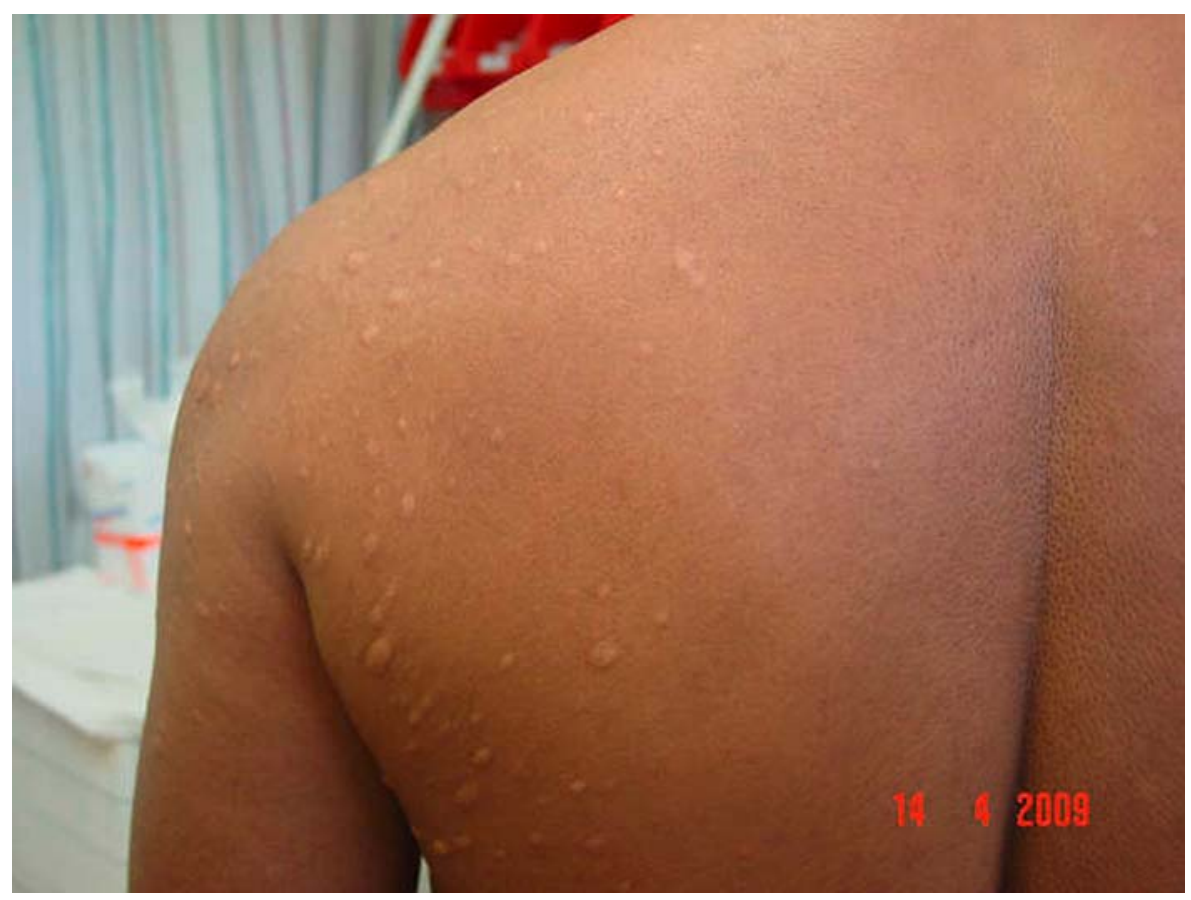

Fig. 2. Minimal dermal perivascular chronic inflammatory cells infiltrate.

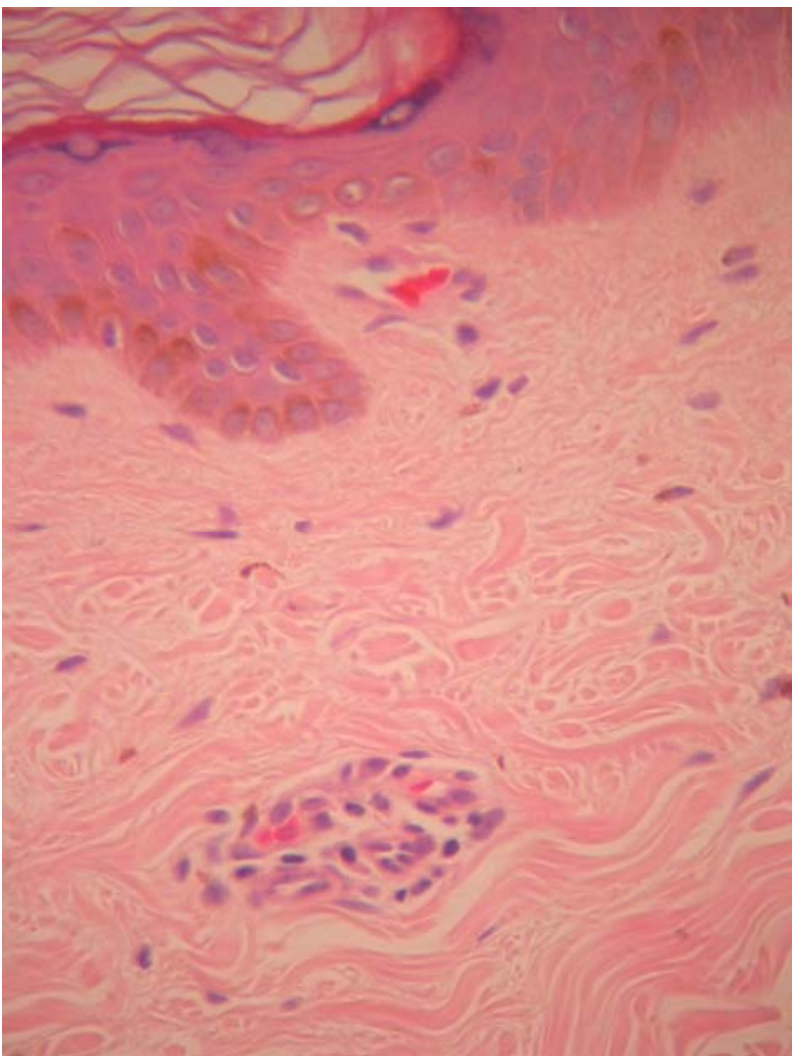


Fig. 3. Elastic stain (Verhoef-Van Gieson) showing loss of elastic fibers in the superficial dermis.

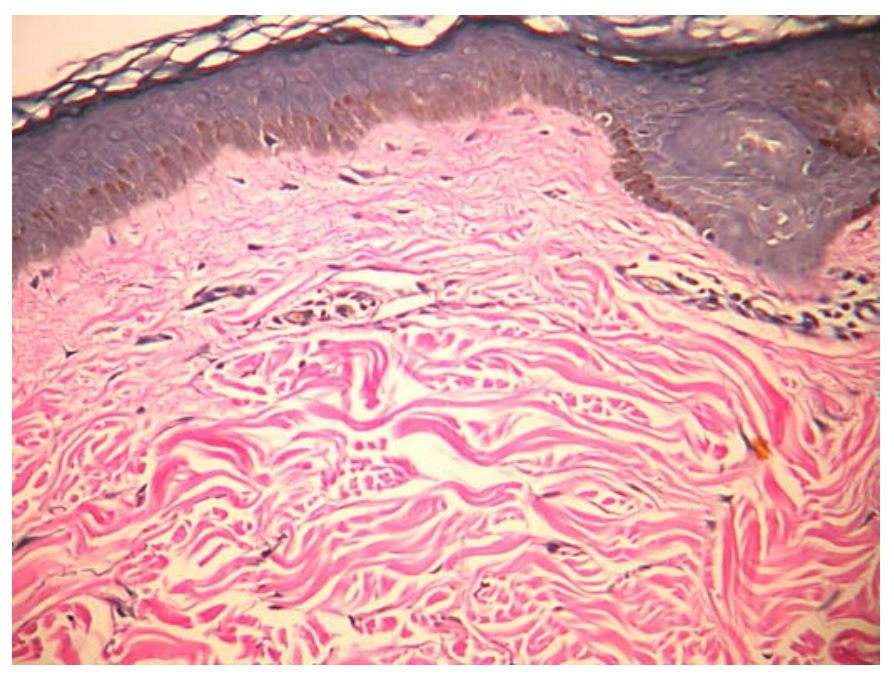




\begin{tabular}{l|l|l|l} 
Case Reports in & $\begin{array}{l}\text { Case Rep Dermatol 2009;1:100-104 } \\
\text { D01: } 10.1159 / 000265699\end{array}$ & Published online: December 22, 2009 & $\begin{array}{l}\odot 2009 \text { S. Karger AG, Basel } \\
\text { ISSN 1662-6567 } \\
\text { www.karger.com/cde }\end{array}$ \\
\hline
\end{tabular}

\section{References}

1 Thibierge MG: Atrophodermie erythemateux en plaques, a progression excentrique. Ann Dermatol Syphil 1891;2:1004-1005.

2 Thibierge MG: Le lupus erythemateux a forme d'atrophodermie en plaques. Ann Dermatol Syphil 1905;6:913-926.

3 Heuss-Zurick E: Beitrag zur Kenntnis der atrophia maculosa cutis. (Anetodermai erythematodes Jadassohn) Monatsschr Prakt Dermatol 1901;32:1-20.

4 Nomland R: Macular atrophy: lupus erythematosus. Arch Dermatol 1932;26:1118-1119 (abstract).

5 Rosen I: Primary macular atrophy: lupus erythematosus (Schweninger and Buzzi). Arch Dermatol 1936;33:580 (abstract).

6 Scull RH, Nomland R: Second macular atrophy: a study of 12 cases occurring in connection with various disorders, with consideration of pathologic relationship. Arch Dermatol 1937;36:809-820.

7 Margarot J, Rimbaud P, Raviore J: Lupus erythemateux fixe et anetodermie de Jadassohn. Bull Soc Dermatol Syphil 1937;44:1830-1831.

8 Milian G, De Dout J: Anetodermie en taches et lupus erythemateux. Bull Soc Dermatol Syphil 1939;46:1003-1008.

9 Lewis GM: Lupus erythematosus (discoid type): macular atrophy (primary). Arch Dermatol 1943;47:759-760 (abstract).

10 Cipollaro AC: Macular atrophy (Schweninger and Buzzi): chronic discoid lupus erythematosus. Arch Dermatol 1952;65:507-509 (abstract).

11 Dupperatt B: Anetodermie type Schweninger-Buzzi. Bull Soc Fr Dermatol Syphil 1954;61:11.

-12 Temime P, Baran LR, Friedman E: Anetodermie pseudomorale et lupus erythemateux chronique. Ann Dermatol Syphil 1971;98:141-146.

13 Ryll-Nardzewski C, Kudejko T, Kudejko J: Remarques sur le lupus erythematosus profond de Kaposi-Ingang et sur L'anetodermie erythematoide. Ann Dermatol Syphil 1960;87:627-636.

-14 Venencie PY, Winkelmann RK, Moore BA: Anetoderma. Clinical findings, associations, and long-term follow-up evaluations. Arch Dermatol 1984;120:1032-1039.

15 Bergman R, Friedman-Birnbaum R, Hazaz B, Cohen E, Munichor M, Lichtig C: An immunofluorescence study of primary anetoderma. Clin Exp Dermatol $1990 ; 15: 124-130$

16 Hodak E, Shamai-Lubovitz O, David M, Hazaz B, Katzenelson-Weissman V, Lahav M, et al: Immunologic abnormalities associated with primary anetoderma. Arch Dermatol 1992;128:799-803.

17 Jubert C, Cosnes A, Clerici T, Gaulard P, Andre P, Revuz J, et al: Sjogren's syndrome and cutaneous B cell lymphoma revealed by anetoderma. Arthritis Rheum 1993;36:133-134.

18 Mildrat W: Auftreten von anetodermia erythematosa, vitiligo und alopecia areata auf dem Boden einer pluriglandularen Insuffizienz. Dermatol Monatsschr 1937;104:180-185.

19 Weber FB: Macular atrophy of the skin showing the early raised erythematous stage and ordinary vitiligo. Proc R Soc Med 1917;173-174.

20 Merenlender J: Sur l'etiologie de l'atrophie idiopathique de la peau: un cas d'atrophie maculeuse chez une malade atteinte de sclerose en plaques. Ann Dermatol Syphil 1933;4:593-612.

-21 Hodak E, David M: Primary anetoderma and antiphospholipid antibodies review of the literature. Clin Rev Allerg Immunol 2007;32:162-166.

-22 Hodak E, Feuerman H, Molad Y, Monselise Y, David M: Primary anetoderma: a cutaneous sign of antiphospholipid antibodies. Lupus 2003;12:564-568.

23 Hodak E, Feuerman H, David M: Primary anetoderma is a cutaneous sign of antiphospholipid antibodies. J Am Acad Dermatol 2008;58:351.

-24 Disdier P, Harlé JR, Andrac L, Verrot D, Bolla G, San Marco M, et al: Primary anetoderma associated with the antiphospholipid syndrome. J Am Acad Dermatol 1994;30:133-134. 
25 Kriseman YL, Nash JW, Hsu S: Criteria for the diagnosis of antiphospholipid syndrome in patients presenting with dermatologic symptoms. J Am Acad Dermatol 2007;57:112-115.

-26 Macedo de Souza E, Christofoletti Daldon PE, Cintra ML: Anetoderma associated with primary antiphospholipid syndrome. J Am Acad Dermatol 2007;56:881-882.

27 Frances C, Niang S, Laffitte E, le Pelletier F, Costedoat N, Piette JC: Dermatologic manifestations of the antiphospholipid syndrome. Arthritis Rheum 2005;52:1785-1793

28 Fernandez-Galar M, Espana A, Lloret P: Systemic lupus erythematosus-associated anetoderma and anti-phospholipid antibodies. Clin Exp Dermatol 2003;28:39-42.

29 Alvarez-Cuesta CC, Raya-Aguado C, Fernandez-Rippe ML, Sanchez TS, PerezOliva N: Anetoderma in a systemic lupus erythematosus patient with anti-PCNA and antiphospholipid antibodies. Dermatology 2001;203:348-350.

- 30 Bergman R, Friedman-Birnbaum R, Hazaz B, Cohen E, Munichor M, Lichtig C: An immunofluorescence study of primary anetoderma. Clin Exp Dermatol 1990;15:124-130.

- 31 Hodak E, Shamai-Lubovitz O, David M, Hazaz B, Katzenelson-Weissman V, Lahav M, et al: Immunologic abnormalities associated with primary anetoderma. Arch Dermatol 1992;128:799-803.

-32 Weinstein S, Piette W: Cutaneous manifestations of antiphospholipid antibody syndrome. Hematol Oncol Clin North Am 2008;22:67-77.

- 33 de Souza EM, Daldon PE, Cintra ML: Anetoderma associated with primary antiphospholipid syndrome. J Am Acad Dermatol 2007;56:881-882.

34 Romaní J, Pérez F, Llobet M, Planagumá M, Pujol RM: Anetoderma associated with antiphospholipid antibodies: case report and review of the literature. J Eur Acad Dermatol Venereol 2001;15:175-178. 